\title{
The Nigerian Diaspora's Contributions to the Development of Higher Education
}

\author{
Sharkdam Wapmuk
}

\begin{abstract}
While engagement with the Nigerian diaspora has focused on attracting investment and remittances, recently, attention has also shifted to its contribution to the development of higher education. The descriptive and qualitative study on which this article is based drew on secondary data that was analysed through content analysis. The findings revealed that $\mathrm{a}$ combination of factors motivated Nigerians, including intellectuals, to emigrate, particularly in the I980s and I990s. This compounded existing problems in Nigeria's higher education sector. Since I999, successive governments have engaged the diaspora in national development, including higher education. The study found that through the Linkages with Experts and Academics in the Diaspora Scheme, the United Nations Development Programme's Transfer of Knowledge Through Expatriate Nationals, and the World Bank assisted Nelson Mandela Institution, known as the African University of Science and Technology, as well as alumni associations in the diaspora, Nigerian diaspora academics have been returning home to transfer knowledge in universities. Other contributions include projects, donations, and programmes. However, several challenges constrain the tapping of their full potential. The article recommends that, the Nigerian government should create an enabling environment, ensure clarity of expectations, provide adequate funding and adopt long-term approaches to engage with the Nigerian academic diaspora.
\end{abstract}

Key Words: Nigerian diaspora, higher education, brain-drain, brain-gain, knowledge transfer

L'engagement avec la diaspora nigériane s'est concentré sur l'attraction des investissements et des envois de fonds, mais récemment, l'attention s'est également tournée vers sa contribution au développement del'enseignement

ABOUt the AUthor: SHARKDAM WAPMUK, Nigerian Defence Academy, Nigeria. Email: swapmuk@nda.edu.ng 
supérieur. L'étude descriptive et qualitative sur laquelle se fonde cet article s'est appuyée sur des données secondaires qui ont été analysées par analyse de contenu. Les résultats des analyses ont révélé qu'une combinaison de facteurs a motivé les Nigérians, y compris les intellectuels, à émigrer, en particulier dans les années 80 et 90. Cela a aggravé les problèmes existants dans l'enseignement supérieur au Nigéria. Depuis I999, les gouvernements successifs ont engagé la diaspora dans le développement national, y compris l'enseignement supérieur. L'étude a révélé que, grâce à l'apport du Linkages with Experts and Academics in the Diaspora Scheme (Programme de la diaspora sur le lien avec les experts et les universitaires), du Transfer of Knowledge Through Expatriate Nationals (Initiative de transfert des connaissances par l'intermédiaire des expatriés) du Programme des Nations Unies pour le développement, et de l'African University of Science and Technology (Université africaine des sciences et de la technologie) parrainée par la Banque mondiale, ainsi qu'au soutien des associations d'anciens étudiants Nigérians dans la diaspora, les universitaires de la diaspora sont rentrés chez eux pour transférer leurs connaissances dans les universités. Il y a eu d'autres contributions qui comprennent des projets, des dons et des programmes. Cependant, l'exploitation de leur plein potentiel se heurte à plusieurs défis. L'article recommande que le gouvernement nigérian crée un environnement propice, assure la clarté des attentes, fournit un financement adéquat et adopte des approches à long terme pour s'engager avec la diaspora universitaire nigériane.

Mots clés: diaspora nigériane, enseignement supérieur, fuite des cerveaux, gain de cerveaux, transfert de connaissances

\section{Introduction}

This article examines the contemporary interventions and contributions of the Nigerian diaspora to the development of higher education in their homeland. It argues that Nigeria's past engagements with its diaspora focused on attracting the diaspora for national development, conceived as the inflow of investment and remittances, rather than on academic and skills transfer. The discourse on diaspora and development in general, and specific national contexts has received increasing attention in scientific and political debates in recent years (Bréant, 20I3; Lampert, 20I0; Mercer, Page, and Evans, 2008; Marchand, Langley and Siegel, 2015; Oyebade and Falola, 20I7). This article focuses on the discourse on reclaiming the African diaspora to support higher education and African countries' development (Langa and Fongwa, 20I8; Zeleza, 20I3). It has been argued that Nigerian emigration is characterised by a diversity of flows, including cross-border movement (Adepoju, 2005). Highly-skilled Nigerians' migration to several destination countries occurred in different phases (de Haas, 2006). Slavery, colonial labour policies, military authoritarianism, post-colonial conflict, including the Nigerian civil war of I967-I970, and economic hardship occasioned by Structural Adjustment Programmes (SAP) and neoliberalism have all propelled Nigerians into the diaspora (Wapmuk, Akinkuotu and Ibonye, 20I4). Highly-trained Nigerians' migration to more developed and economically advanced countries has been described as 'brain drain'. The International Organization for Migration (IOM) notes that Nigerians constitute the largest population of migrants from developing countries in Africa to industrialised countries in Europe, the United States (US) and elsewhere (IOM, 20I2).

Nigeria's returned to democratic government in I999 after almost three decades of military authoritarian rule, opening up a new vista in terms of government-diaspora relations. This is evident in increased efforts by successive administrations to attract the Nigerian diaspora, not only to identify with the country as their homeland, but also to contribute to its development in general, and higher education in particular. The philosophy behind Nigeria's current efforts to engage the diaspora to revamp higher education is driven by the fact that education constitutes the bedrock of national development (Kulild, 20I4; Acemoglu and Robinson, 2013). Accordingly, as opposed to the brain-drain that characterised the I980s and I990s, attracting Nigerians to the home-front is seen as a form of 'brain-gain' (Gueye, 20I9) or what Theroux (20I9) referred to as "brain circulation". Aikins and White (20II) argue that education is one of the strategies through which states can draw from their diaspora. An important issue is how to facilitate collaboration and tap resources from the diaspora for higher education in Africa (Zeleza, 2013, 2004).

The major question that this article addresses is: to what extent has the Nigerian diaspora keyed into the country's higher education sector? It also seeks answers to related questions. What is the general understanding of the diaspora, and more specifically, what constitutes the Nigerian diaspora? What is the state of higher education in Nigeria? How has the Nigerian government engaged the Nigerian diaspora to contribute to higher education in the country? What constitutes the nature of Nigerian diaspora interventions and contributions to higher education? What challenges militate against the diaspora's engagement for the development of higher education in Nigeria and what is the way forward? A descriptive and qualitative approach was adopted to answer these questions. Data was gathered from secondary sources including books, monographs, journal articles, government reports and the websites of government institutions and international organisations, and was analysed through content analysis. 
The article commences with an introduction, followed by a conceptual clarification of the diaspora and the Nigerian diaspora. The third section examines the state of higher education in Nigeria, while section four discusses Nigerian government-diaspora relations and engagement of the Nigerian diaspora. Section five focuses on the Nigerian diaspora's interventions and contributions to higher education. Section six discusses the challenges confronting diaspora engagement in the development of higher education in Nigeria and offers suggestions on the way forward, before concluding.

\section{Conceptual and Analytical Framework}

The term diaspora is not only contested and dynamic, but its usage also varies among groups over time, depending on their ideological standpoint.

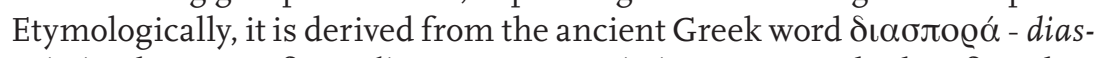
peirein 'disperse', from dia 'across' + speirein 'scatter', which referred to spreading or scattering of seeds. Over the years, scholars have sought to clarify the concept of diaspora in general and specific contexts (Clifford, I994; Pasura, 20I0; Safran, I991; Tololyan, I996). At the level of general theoretical discourse, the most commonly cited work is that of Safran (I99I), Clifford (I994) and Cohen (I997). In Diasporas in Modern Societies: Myths of Homeland and Return, Safran (I99I) argues that the degree of force that initiates a population's dispersal tends to establish what counts as a diaspora, semi-diaspora or non-diaspora. He adds that only when a population faces a destroyed homeland and/or its own expulsion, and collectively experiences trauma as a result, can one talk of a diaspora. Cohen (I997) identified five types of diaspora, including victim, labour, trade, imperial and cultural. However, not all the diaspora was forced. Voluntary migrations in the post-colonial era also account for the volume of the African diaspora in developed and economically advanced countries. This is reflected in the IOM's (2OI2) migration policy that defined the diaspora as "emigrants and their descendants, who live outside the country of their birth or ancestry, either on a temporary or permanent basis, yet still maintain affective and material ties to their countries of origin" (Agunias and Newland 20I2, p. I5). Scholars have recognised the conceptual challenges and lack of theoretical clarity in relation to the term diaspora (Pasura, 20I0; Acemoglu and Robinson, 20I3). Tololyan (I996, p. 5) notes that the concept, which was used to describe Jewish, Greek and Armenian dispersion, "now shares meanings with a larger semantic domain that includes terms like immigrant, expatriate, refugee, guest worker, exile community, overseas community, ethnic communities". Dirlik (2004) asserts that the concept is sometimes taken for granted and makes a strong case for a more complicated understanding. There is no doubt that this concept can be appropriated for various purposes and agendas including ideology, nationalism, and to serve certain interests, including propaganda.

To avoid the conceptual ambiguity arising from multiple interpretations, for the purposes of this article, we adopt the definition advanced by the Nigerians in Diaspora Commission (NiDCOM). It defines the Nigerian diaspora as any Nigerian who lives and works abroad and has an interest in contributing to Nigeria's socio-economic, political, technological and industrial development. This definition draws on the African Union's (AU) definition of the African diaspora. According to the AU, "The African Diaspora consists of peoples of African origin living outside the continent, irrespective of their citizenship and nationality and who are willing to contribute to the development of the continent and the building of the African Union" (AU, n.d.). It is important to note that the Nigerian diaspora does not present as a single homogenous ethnic group, but a number of ethnic groups, whose identities are underpinned and shaped by their country of origin. Accordingly, the Nigerian diaspora establishes ethnic and religious organisations side by side with umbrella bodies such as the Nigerians in the Diaspora Organization (NIDO), and various branches such as NIDO in the US, Europe, Russia and Asia, as well as the Central Association of Nigerians in the United Kingdom (CANUK), Nigerian Peoples' Forum USA and the Organisation for the Advancement of Nigerians USA, amongst others. These organisations serve a dual purpose. Firstly, they support members and connections of the Nigerian diaspora within host countries, and, secondly, they connect members with their mother land.

This article adopts as its framework of analysis the diaspora-development nexus and typology proposed by Mohan (2002) who divided diaspora development into three categories. According to Mohan (2002), while development 'in' the diaspora refers to the use of diasporic connections in the immediate locality to ensure the social and economic well-being of members of the diaspora; development 'through' the diaspora expands on development ' $i n$ ' the diaspora by engaging global as well as local networks; and development ' $b y$ ' the diaspora refers to the economic, political, socio-cultural, and educational diasporic flows that facilitate development of homelands (Mohan, 2002, p. I23). Of concern to this article is the diaspora's contribution to the development of higher education in the home country. The article also draws theoretical insights from Arif Dirlik's Global Modernity: Modernity in an Age of Global Capitalism, and Intimate others: [private] nations and Diasporas in an age of globalization, as well as Arjun Appadurai's Disjunction and Differences in Global Cultural Economy. These scholarly works help to shed light on the complex notion of diaspora in the age of globalisation and transnationalism. Globalisation, that is reflected in contemporary global flows of people, ideas and capital, has 
led to profound changes in transnational interactions, affinities, forms of connectivity and understanding of the whole notion of diaspora. Transnationalism is related to identity and belonging, both of which have tendency to evolve through the generations. It is therefore not surprising that, unlike the first or second generation, third or fourth generation diaspora may have no memory of home. Dirlik and Appadurai link the formation of the African diaspora to the evolution of a globalised and racialised capitalism. Slavery, colonial labour policies, post-colonial conflict and economic hardship have all propelled Africans into the diaspora that is becoming ever more diffuse. Dirlik (2004) argues that contemporary cultural analysis of diaspora or diasporic identities focuses on the problematic of national identity and/ or the necessity of accommodating migrant cultures. The concept of diaspora or diasporic identity is useful in deconstructing claims of national cultural homogeneity. It is also important in expanding the horizon of cultural differences and challenging cultural hegemony at a time when the accommodation of cultural differences may be more urgent than ever in the face of the globalising world. Appadurai (I990, p. 297) also notes that, for the diaspora community, there is often tension between "cultural homogenization and cultural heterogenization". Appadurai adds that it is necessary to understand these 'diasporas' and movement of cultural products in order to achieve global competitiveness. The movement of monies and knowledge back home could be positively or negatively deployed in the home country, even as state governments continue to promote national development.

\section{Nigerian Government-Diaspora Relations and Engagement in National}

\section{Development}

Nigerians can be found in many countries of the world. However, the exact extent of this diaspora remains unknown. The Pew Research Center (20I9) estimates that the Nigerian diaspora ranges from two to fifteen million people. The IOM puts the number of Nigerians living in the US at roughly 3.4 million, making them one of the country's largest African immigrant groups. The UK, South Africa, United Arab Emirates (UAE) and other European and Asian countries also have large populations of Nigerians. As noted earlier, several factors propelled Nigerians into the diaspora. These include but are not limited to slavery, colonial labour policies, military authoritarianism, post-colonial conflict, including the Nigerian civil war of I967-1970, and economic hardship occasioned by SAP and neoliberalism. In addition, the prospect of greener pastures, attraction of foreign universities, and the crisis in the Nigerian education system characterised by recurrent strikes and insecurity have contributed to the emergence of the academic diaspora. The emergence of this diaspora hinges on Nigerians' pursuit of academic excellence abroad. According to the IOM (20I2, p. I4), Nigerians are "highly educated with approximately 62 per cent possessing a bachelor's degree, a master's degree or a doctorate. Approximately 78 per cent are employed, with a significant segment in skilled professions, such as health or education". Furthermore, the IOM's mapping of Nigerian health and education professionals in the US found that, of "the professional fields in the education sector, respondents were most interested in higher education, curriculum development and education policy" IOM (2OI2, p. 2I). The Nigerian diaspora thus includes a high proportion of educated persons that are willing to contribute to higher education in the country.

The Nigerian government signed the Nigerians in Diaspora Commission Establishment Bill in 20I7, following which a Diaspora Commission (DC) was established. The DC liaises with Nigerians in and from the diaspora to contribute human capital and material resources, including expertise, for national development. In addition, the Federal Republic of Nigeria produced a Draft National Policy on Diaspora Matters in 20I6, which received input from Nigerians in the diaspora. While this document does not expressly define the academic diaspora, it states that, "The NUC [National Universities Commission] shall have the responsibilities of designing and implementing programmes aimed at linking experts and academics in the Diaspora to the development of university education in Nigeria." In collaboration with the IOM, the government produced the National Migration Policy 2015, which addresses issues relating to migration, including safe labour migration. In terms of engagement, while the government has sought to engage its diaspora in the past, this was intensified following Nigeria's return to civilian democratic rule in May I999 (Alli, 2010).

During President Olusegun Obasanjo's administration (I999-2007), Nigerians living abroad were officially recognised as valuable stakeholders and partners in the country's development. Apart from interacting with the Nigerian diaspora community during his trips abroad, Obasanjo introduced novel initiatives aimed at bringing home Nigerian professionals and experts living and working abroad According to Akinrinade and Ogen (20II), discussions between the president and the diaspora community centred on maximising the latter's contribution of human resources towards Nigeria's development. This paved the way for the establishment of a global umbrella organisation for all Nigerian diaspora in 200I known as the Nigerians in the Diaspora Organisation (NIDO). Branches were established in the US, Europe, Russia, and Asia. Other diaspora organisations include the Central Association of Nigerians in the United Kingdom (CANUK), the Nigerian Peoples' Forum USA, the Organisation for the Advancement of Nigerians USA, and other pan-ethnic groupings. Also in 
200I, the Directorate of Technical Cooperation in Africa (DTCA) was formed to attract professionals of Nigerian and African descent to invest their knowledge, skills and expertise in African economies.

Tangible outcomes from the government-diaspora interactions that followed include the government's decision in 2002 to allowed Nigerians to acquire foreign citizenship without forfeiting their Nigerian citizenship; and the establishment of the Nigerian National Volunteer Service (NNVS) as an additional institution for diaspora engagement in 2003 (Mberu and Pongou, 20I0). The NNVS initiated the first annual Science and Technology Conference between Nigerians at home and abroad in 2005, in Abuja. The success of this event led to the first Diaspora Day celebrations, alongside the second Science and Technology Conference in 2006. While 76 members of the diaspora attended the 2005 conference, 200 were present the following year (Akwani, 20I3). In 2005, the president declared July $25^{\text {th }}$ as Nigeria Diaspora Day to recognise and celebrate the individual and collective success of Nigerians abroad as well as their contribution to national development. In 2008, former President Umaru Musa Yar' Adua opened the second Diaspora Day celebrations and the third Science and Technology Conference under the theme, Connecting Nigeria with its Diaspora, that attracted around 400 Nigerians living abroad (Akinrinade and Ogen, 20II, p. 82). Since then, the annual forum has brought together a broad spectrum of Nigerian professionals, entrepreneurs, and investors to engage with Nigerians and the government. The discussions during Diaspora Day 20I9, held from July $24-25^{\text {th }}$, centred on the power of the Nigerian diaspora for national development; integrating the diaspora into the Economic Recovery and Growth Plan (ERGP), and the Nigerian diaspora's return to serve the country (African Courier, July 24 20I9). The National Assembly (Senate and House of Representatives) has pledged to provide legislative support to the Nigerian diaspora through debates on the diaspora policy, and support and voting rights for Nigerians abroad (Akwani, 20I3). The latter remains a challenge given issues relating to managing elections and counting votes even within Nigeria.

\section{The Nigerian Diaspora's Interventions and Contributions to Higher}

\section{Education}

Nigeria's engagement with its diaspora previously focused more on remittances than academic and skills transfer (Binaisa, 2013). The reason behind the decision to harness the diaspora to renew Nigerian higher education lies in the fact that Nigerian academics and other professionals' emigration constitutes a brain-drain. This is occurring at a time when Nigerian higher education institutions are confronted by demands for increased access and enrolment, as well as the expansion of the higher education sector, which requires more highly-trained academics. Despite the ethnic diversity in the country, it has been argued that the Nigerian academic diaspora seems united in its resolve to intervene and bridge the intellectual and economic gaps that afflict higher education in Nigeria (Oloruntoba, 2020). It is against this backdrop that we examined the Nigerian diaspora's contributions to higher education.

The Nigerian diaspora's contributions to higher education in Nigeria can be gleaned from the perspectives of knowledge transfer and other interventions. Knowledge transfer aims to develop science, technology, and tertiary academic programmes, and to promote human capacity building. According to Ogen (20I7), it has promoted linkages with academics and professionals abroad. Some have responded to the call to relocate to Nigeria on a short-term basis in order to contribute to national development through engagement in teaching, research, and community service in the Nigerian university system (Ogen, 20I7). The knowledge exchange programme in Nigerian universities is facilitated by the National Universities Commission (NUC) and the Nigerian National Volunteer Service (NNVS).

In 2007, the NUC established the Linkages with Experts and Academics in the Diaspora Scheme (LEADS), a programme which began as the Nigerian Experts and Academics in Diaspora Scheme (NEADS). The major objective of LEADS is to attract experts and academics of Nigerian extraction in the diaspora on a short-term basis, usually between three and nine months, to contribute to the enhancement of education in the country's universities. The Nigerian government calls for applications for shortterm teaching appointments, especially in the areas of Information and Communications Technology (ICT), management science and business administration, mathematics, medicine and dentistry, mining engineering, natural sciences, and oil and gas engineering (NUC, 2020). Incentives comprise a monthly stipend of US\$2,500, a return economy class air ticket, and accommodation and local travel expenses relating to the programme, with the latter two provided by the host university (NUC, 2020).

According to the NUC (2020), a total of 62 LEADS scholars (34 from the US, I 6 from the UK, three from Canada, two from Ireland, Trinidad and Tobago, the Netherlands and the West Indies, respectively, and one from Russia) rendered services in various Nigerian universities before the program came to an end in 20I7. Sixteen served the NUC as consultants and 46 worked at universities. The Universities of Ibadan; Calabar; Ilorin; Abuja; Maiduguri, Nigeria Nsukka; Lagos; Benin; and Jos have benefitted from the services of LEADS scholars, as have the Federal University of Technology Owerri, Bayero University Kano, Federal University Otuoeke, Obafemi Awolowo University Ile-Efe, and the National Open University of Nigeria. State universities in Uli, Ekpoma, Kaduna, Osun and Nassarawa, 
and Covenant University also welcomed these academics (NUC, 2020; Ogen, 20I7). The scheme has been credited with converting brain-drain to brain-gain; enhancing skills acquisition in rare areas of expertise such as the installation of digital X-ray machines for panoramic and cephalometric radiographs in clinics; encouraging industry experts to participate in teaching, research and cross-fertilisation of ideas in Nigerian universities; enrichment of the Nigerian curriculum review process with modern, high tech and new trends in relevant disciplines; and enhancing reintegration of experts into their heritage and community life (NUC, 2020).

The United Nations Development Programme's (UNDP) Transfer of Knowledge Through Expatriate Nationals (TOKTEN) was established in I977 (Meyer and Brown, I999) to tap into the expertise of highly skilled expatriates by assisting them to return to their home country for visits of between three weeks and three months. These expatriates engage in various development projects or undertake teaching assignments at local universities (Ogen, 20I7). In 20II, the TOKTEN scheme attracted some 900 Nigerian professionals living abroad to return home to provide technical assistance in critical economic sectors, including higher education (Mayah and Yusuf, 20II). The UNDP has provided US\$I million (equivalent to Ni5o million) to cover participants' travel and living expenses. Nigerian professionals from Asia, France, the US, Russia, Britain, Canada, Israel, Japan, Cuba, and other countries have offered their services.

Alumni abroad have also made significant contributions to the development of the country's higher education system. Several Nigerian universities have established diaspora alumni associations, which offer donations or facilitate academic exchange programmes. Ogen (20I7) notes that these alumni have facilitated personnel training, library development, and access to research grants, among other things. For example, between 2003 and 2007, alumni of the Faculty of Arts in Obafemi Awolowo University, Ile-Ife who are based in South Africa, the UK and the US donated books and cash to the faculty. Many junior academics in the faculty also benefitted from research and training abroad through the linkages provided by alumni in various institutions in Europe and America (Ogen 20I7).

The Nigerian government is promoting the development of science and technology through a World Bank assisted Nelson Mandela Institution, the African University of Science and Technology (AUST) that was established in Abuja in 2007. The AUST offers graduate education programmes with a focus on the development needs of African countries, particularly in the areas of petroleum engineering, theoretical physics, materials science and engineering, pure and applied mathematics, and computer science and engineering (Ogen, 20I7; AUST, 20I5). The university, which hosts visiting scholars from the Nigerian and other African diaspora, partners with local and international institutions dedicated to science and technology research. These include the University of Ibadan; African Institute of Science and Mathematical Sciences, South Africa; IIT Bombay, University of Aizu, Japan; and Kennesaw State University and the Science Initiative Group (SIGA) in the US (Ogen, 20I7; AUST, 20I5).

While many of the development and cultural organisations established by the Nigerian diaspora as well as individual members have shown an interest in the development of Nigeria's higher education system, not as many have made direct contributions (Marchand, Langley and Siegel, 20I5). According to Cuevas-Mohr (20I9), their contributions mainly consist of remittances to family members and/or households in need of support. In terms of education, members of the Nigerian diaspora and their organisations have participated in projects, and advocacy and support activities. Some work to increase Nigerian children's access to education (Marchand, Langley and Siegel, 20I5) in addition to improving the quality of education back home. For example, the Nigeria Vater Abraham Foundation (VAF), a diaspora organisation in Germany, supports widows by donating money for their children's school fees, books, and other forms of support, from primary and secondary school, to tertiary education. Developmental and cultural organisations in Germany also support occupational training for older children such as a computer courses and facilitate German/Nigerian exchange programmes for Nigerian university students. The Engineering Forum of Nigerians (EFN) that was established by UK-based Nigerian engineers in 2002 to promote engineering education and development in Nigeria (Lampert, 20I0) has advocated that the "teaching of engineering in the Nigerian university system should move away from its overbearing focus on theory towards better preparing graduates for the practical and commercial aspects of the profession" (Lampert, 20Io, p. I74). The association launched the Higher Education Engineering Challenge (HEEC) at the National Engineering Centre (NEC) in Lagos in 2006 (Lampert, 20IO). This annual competition requires undergraduate engineering and technology students to design an innovative and marketable engineering product, device, or system relevant to an issue "considered of vital importance to national development" (Lampert, 20I0, p. I75). Through this programme, the EFN identifies and supports engineering and technology undergraduates in higher education institutions in the country.

\section{Challenges confronting Diaspora Engagement in the Development of Higher Education in Nigeria}

While Ogen (2017) argues that Nigerians are eager to come home and contribute to national development, several challenges hamper the full realisation of the Nigerian diaspora's potential to promote the development 
of higher education and science in the country. Firstly, there is no reliable data on Nigerians abroad. This is partly due to poor documentation by the Nigerian immigration authorities, and host countries' failure to consider naturalised and second-generation Nigerians in their statistics. The Ministry of Foreign Affairs (MFA) estimates that around 20 million Nigerians are living in the diaspora (Edobor, 20I7). The lack of accurate data poses a challenge to planning and engagement of Nigerians in strategic interventions in higher education. The second challenge is the lack of an enabling environment arising from inadequate infrastructure such as electricity, functional roads, and educational structures.

Thirdly, insecurity poses a huge challenge to the Nigerian diaspora. Since Nigeria returned to democratic rule in I999, there have been recurrent reports of violence and criminality in various parts of the country. These include, but are not limited to, militancy in the Niger Delta, ethno-religious conflicts, farmers-herders' clashes, cybercrime, armed robberies, armed banditry, kidnappings, and cattle rustling. The multiple security challenges confronting the country have become overlapping and pose very serious challenges to public policy (Mofolorunsho, Idah and Abu-Saeed, 20I9; Egwu, 2015, p. I4; Onuoha and Okolie-Osemene, 2019). The Nigerian state's failure to secure citizens' lives and property is a major hindrance to the diaspora's engagement in the development of higher education. Fourthly, Nigerians living abroad confront difficulties in sending remittances home to support the higher education sector. Given that formal transfer channels are expensive, some Nigerian diaspora resort to informal channels (Cuevas-Mohr, 20I9). The government thus lacks accurate information on how best to plan and harness diaspora resources for the development of this sector.

Fifth, the lack of a framework to integrate returning Nigerians constrains the diaspora's engagement in higher education. The country has yet to settle the question of how returning members of the diaspora, particularly the older generations, will be reintegrated. The National Policy on Diaspora Matters, which should address these concerns, including issues such as the diaspora's right to vote, has remained in draft form since 2016 .

Finally, the Nigerian government's poor response to emergency situations confronted by the diaspora (Edobor, 20I7) such as disasters, wars, xenophobic attacks, and pandemics has discouraged them from contributing to their country's development. A case in point is Nigerians trapped abroad as a result of the shutdown of borders of countries due to COVID-I9. These included 2,000 Nigerians in the US, UK, UAE and China, and 200 in Sudan, as well as students, who want to return home (Ukwu, 2020). While the US and other countries have evacuated their citizens from Nigeria, the Nigerian government has been slow in offering a like response.

\section{Concluding Remarks}

This article examined the Nigerian diaspora's contributions to the development of higher education in Nigeria. The country's higher education sector suffers a number of weaknesses that result from a complex web of factors that have their roots in the colonial and post-colonial eras. Neglect of public higher education, coupled with economic hardship due to the collapse in oil prices, the adoption of the SAP regime, and military regimes that clamped down on academia, propelled Nigerian intellectuals to migrate during the ig80s and I990s. Africa is among the regions that are most seriously affected by the outflow of skilled citizens. Since Nigeria returned to democratic rule in I999, it has established and funded various initiatives to encourage the diaspora's engagement in the country's higher education system.

Our examination of the diaspora's contributions to higher education and science in Nigeria revealed that the focus has been on knowledge transfer as well as direct interventions through projects, advocacy and the organisation of programmes in tertiary institutions. Through the LEADS, TOKTEN, AUST, and Nigerian alumni associations in the diaspora, experts and academics of Nigerian extraction have returned home to transfer knowledge in universities, and have also facilitated academic linkages and collaborations with academics and institutions in other parts of the world. However, several challenges, including insecurity, inaccurate data, the lack of an enabling environment, and the Nigerian government's slow response when members of the diaspora find themselves in emergency situations, hamper the tapping of the diaspora's full potential in developing higher education in the country.

The Nigerian government should strengthen and support the NIDO to mobilise and leverage the expertise, skills and experience of Nigerians living overseas. The Diaspora Commission, in collaboration with the NIDO and its branches worldwide should undertake a census of Nigerians in the diaspora in order to gather accurate data to inform planning. The government also needs to create a conducive environment, including security, for Nigerians at home and in the diaspora. Section I4 (I) (b) of the Constitution of the Federal Republic of Nigeria states that, "the security and welfare of the people shall be the primary purpose of government" (Nigerian Constitution, I999 as amended). The government should facilitate and ease the transfer of remittances and clearly identify areas in which the diaspora can contribute. Finally, the government should fast-track the completion of the National Policy on Diaspora Matters which has been in draft form since 2016 .

In conclusion, in order to maximise the benefits of academic diaspora engagement, there is a need for clarity on what can be expected of them, 
and to ensure adequate funding. The current short-term approach to such engagement should be replaced by well-planned, institutional long-term approaches.

\section{References}

Acemoglu, D., and Robinson, J.A. (2013). Why nations fail: The origins of power, prosperity and poverty. London: Profile Books.

Adepoju A. (2005). Creating a borderless West Africa: Constraints and prospects for intra-regional migration. Migration without Borders Series, UNESCO, I-I3.

African Courier. (20I9, July 24). Nigeria declares July 25 National Diaspora Day. Retrieved from https://www.theafricancourier.de/africa/nigeriadeclares-25-july-national-diaspora-day/ on I8 June, 2020.

African Union. (n.d.). The Diaspora Division. Retrieved from https:// au.int/en/diaspora-division\#: :text=The\%2oAfrican\%2oUnion\%20 defines\%2othe,constitutive\%2oact\%2odeclares\%2othat\%2oit, on I2 January, 202I.

Agunias, D.R., and Newland, K. (2012). Developing a road map for engaging diasporas in development: A handbook for policymakers and practitioners in home and host countries. Geneva and Washington, DC: IOM and Migration Policy Institute.

Aikins, K., and White, N. (20II). Global diaspora strategies toolkit: Harnessing the power of global diasporas. Dublin: Diaspora Matters.

Akhaine, S.O. (2016). Education in the age of neoliberalism: Local and external contexts. Retrieved from tell.ng/education-age-neoliberalismlocal-external-contexts/ on 28 June, 2020.

Akinrinade, S., and Ogen, O. (20II). Historicizing the Nigerian Diaspora: Nigerian migrants and homeland relations. Turkish Journal of Politics 2(2), 7I-85.

Akwani, O. O. (2012, November I8). Nigeria: Turning the 'brain drain' into 'brain gain. Retrieved from https://imdiversity.com/villages/global/ nigeria-turning-the-brain-drain-into-brain-gain/Web on 28 June, 2020.

Alli, W. O. (20I0). Nigeria and Africans in the diaspora. In: B.A. Akinterinwa (ed.) Nigeria's national interest beyond Nigeria, pp. 255-280. Ibadan: Bolytag International.

Appadurai, A. (I990). Disjuncture and Difference in Global Cultural Economy. Theory, Culture and Society 7(2), 295-310.

AUST. (20I5). About AUST-African University of Science and Technology (AUST). Retrieved from http://www.aust.edu.ng/about-aust/ on 22 June, 2020

Binaisa, N. (20I3). Nigeria @ 50: Policies and practices for diaspora engagement. In: M. Collyer (ed.) Emigration nations' policies and ideologies of emigrant engagement, pp. 226-251. New York: Palgrave Macmillan.
Bréant, H. (20I3). What if diasporas didn't think about development? A critical approach of the international discourse on migration and development. African and Black Diaspora: An International Journal 6(2), 99-II2.

Cuevas-Mohr, H. (20I9). Nigerian diaspora and remittances: Transparency and market development. Retrieved from https://imtconferences. com/nigerian-diaspora-remittances/ on 22 June, 2020.

De Haas, H. (2006). International migration and national development: Viewpoints and policy initiatives in countries of origin - The case of Nigeria. Oxford: International Migration Institute - University of Oxford.

Dirlik, A. (I994). The postcolonial aura: Third world criticism in the age of global capitalism. Critical Inquiry 20(2), 328-356.

Dirlik, A. (2007). Global modernity: Modernity in the age of global capitalism. Boulder: Paradigm.

Dirlik, A. (2004). Intimate others: [private] Nations and diasporas in an age of globalization. Inter-Asia Cultural Studies 5(3), 49I-502.

Edobor, I.O. (20I7, November II). Critical appraisal of NIDO and the role of the diaspora in facilitating socio-economic development of Nigeria. Paper delivered at the NIDOE AGM 20I7, Lisbon, Portugal.

Egwu, S. (2015). The political economy of rural banditry in contemporary Nigeria. In: M. J. Kuna and J. Ibrahim (eds.) Rural banditry and conflicts in Northern Nigeria, pp. I3-68. Abuja: Centre for Democracy and Development (CDD).

Federal Republic of Nigeria. (1999). The Constitution of the Federal Republic of Nigeria 1999. Abuja: Government Printer.

Federal Republic of Nigeria. (2016). Draft National Policy on Diaspora Matters. Retrieved from http://diaspora.gov.ng/final-draft-nationalpolicy-on-diaspora-matters.pdf on 22 June, 2020.

Gueye, A. (20I9). From brain drain to brain gain: Countries engaging their Diasporas. Retrievedfromhttps://production-carnegie.s3.amazonaws. com/filer_public/e9/77/eg770ee4-f63c-423e-8876-edbe7a8f5cor/african _diaspora_forum_20I9_gueye.pdf on October 28, 2020

IOM. (2OI2). Mapping exercise for Nigerian health and education professionals in the United States of America. Abuja: International Organization for Migration.

Kulild, V. (20I4, November II). Role of education in ending extreme poverty - Taking a global lead. Speech by Director General of Norad at the Carita seminar on the United Nations Sustainable Development Goals and Post-20I5 Development Agenda in Oslo.

Lampert, B. (20I0). Diaspora and development? Nigerian organisations in London and their transnational linkages with 'home'. PhD thesis, University College London. 
Langa, P.V., and Fongwa, S. (20I8). Introduction: Reclaiming the African diaspora to support African higher education. Journal of Higher Education in Africa 16(I and 2), iv-xvi.

Lawal, F. (20I7). TETFund: A simple breakdown of FG's biggest ever disbursement to schools. Retrieved from http://www.pulse.ng/ communities/student/tetfund-breakdown-of-fgs-biggest-disbursement-to-schools-id6269iI6.html on 22 June, 2020.

Mangala, J. (20I7). Engaging diasporas in development: Contours and outcomes of international policymaking. In: J. Mangala (ed.) Africa and its global diaspora: the policy and politics of emigration, pp. 3-38. New York: Palgrave Macmillan.

Marchand K., Langley S., and Siegel, M. (20I5). Diaspora engagement in development: An analysis of the engagement of the Nigerian diaspora in Germany and the potentials for cooperation. Maastricht: Maastricht Graduate School of Governance (MGSoG).

Mayah, M., and Yusuf, D. (January 24, 20II). TOKTEN: Nigerian experts return to fix critical economic sectors. Retrieved from https:// newafricanpress.com/20II/oI/24/tokten-nigerian-experts-return-tofix-critical-economic-sectors/ on 22 June, 2020.

Mberu, B. U., and Pongou, R. (20I0). Nigeria: Multiple Forms of Mobility in Africa's Demographic Giant. Migration Information Source. Retrieved from https://www.migrationpolicy.org/article/nigeria-multiple-forms-mobility-africas-demographic-giant on 22 June, 2020.

Mercer, C., Page, B., and Evans, M. (2008). Development and the African diaspora: Place and the politics of home. London: Zed Books Ltd.

Meyer, J.B., and Brown, B. (I999). Scientific diasporas: A new approach to the brain drain. World Conference on Science, UNESCO Discussion Paper Series No. 4I.

Modupe, A.F. (20I8). Nigeria diaspora's contributions to national development: A political economy approach. London Journal of Research in Humanities and Social Sciences 18(2), 33-4I.

Mofolorunsho T. B, Idah A. F, and Abu-Saeed, M. (2019). Challenges of national security in Nigeria. International Journal of Research and Innovation in Social Science (IJRISS) III(VII), I78-I84.

Mohan, G. (2002). Diaspora and development. In: J. Robinson (ed.) Development and displacement, pp. 77-I40. Oxford: Oxford University Press.

Mohan, Giles, and Zack-Williams, A.B. (2002). Globalisation from below: Conceptualising the role of the African diasporas in Africa's development. Review of African Political Economy 29(92), 2II-236.

NUC. (2020). Brief update on linkages with experts and academics in the diaspora scheme (leads). Retrieved from https://www.nuc.edu. ng/project/leads/ on 22 June, 2020.
Ogen, O. (20I7). Nigeria: Diaspora engagement policies in national context. In: J. Mangala (ed.) Africa and its global diaspora: The policy and politics of emigration, pp. II3-I42. New York: Palgrave Macmillan.

Oloruntoba, S.O. (March 30, 2020). How Africa's academic diaspora can help revive higher education back home. Retrieved from https:// theconversation.com/how-africas-academic-diaspora-can-help-revivehigher-education-back-home-I3383I on 28 June, 2020.

Olutayo, A.O. (20I7). Money drain, the diaspora remittance issues and higher education in Nigeria. Journal of International Mobility 5,13-42.

Onuoha, F.C., and Okolie-Osemene, J. (20I9). The evolving threat of kidnapping for ransom in Nigeria. In: O.O. Oshita, I. M. Alumona, and F. C. Onuoha (eds.) Internal security management in Nigeria: Perspectives, challenges and lessons, pp. 233-258. Singapore: Palgrave Macmillan.

Oyebade, A., and Falola, T. (20I7). Introduction. In: T. Falola and A. Oyebade (eds.) The new African diaspora in the United States, pp. I-8. New York: Routledge.

Pasura, D. (2010). Competing meanings of the diaspora: The case of Zimbabweans in Britain. Journal of Ethnic and Migration Studies 36(9), I445-I46I.

Pew Research Centre. (20I9, April 3). Immigrants sent a record amount of money home to sub-Saharan African countries in 20I7. Retrieved from https://www.pewresearch.org/fact-tank/20I9/04/03/immigrants-sent -a-record-amount-of-money-home-to-sub-saharan-african-countries -in-20I7/, on I2 January, 202I.

Safran, W. (I99I). Diasporas in modern societies: Myths of homeland and return. Diaspora: A Journal of Transnational Studies 1(I), 83-99.

TETFUND. (20I5). Guidelines for accessing TETFUND intervention funds. Abuja: TETFUND.

Theroux, K. (January I5, 2019). Harnessing the power of the diaspora: A surgeon's remarkable journey from Africa and back. Retrieved from https://www.carnegie.org/topics/topic-articles/african-academic-diaspora/harnessing-power-diaspora/ on 22 June, 2020.

Tololyan, K. (I996). Rethinking diaspora(s): Stateless power in the transnational moment. Diaspora: A Journal of Transnational Studies 5(I), 3-36.

Ukwu, J. (2020, April I5). COVID-I9: We don't have the resources to bring back Nigerians stranded abroad - FG. Legit News. Retrieved from https://www.legit.ng/I32II09-covid-I9-weve-capacity-mop-nigeriansonyeama.html on 28 June, 2020.

Wapmuk, S., Akinkuotu, O., and Ibonye, V. (2014). The Nigerian Diaspora and National Development: Contributions, Challenges and Lessons from Other Countries. Kritika Kultura, No. 23, School of Humanities, Anteneo De Manila University, Quezon City, Philippines. 
Welde, A.B., Emovwodo, S.O., Saud, M., and Wardhani, B.L.S.W. (2020). Nigeria and Ethiopian Diaspora remittances: Engagement, policy reforms and poverty reduction. Migration and Development. DOI: Io.1080/21632324.2020.1742975.

Zeleza, P. (2004). The African academic diaspora in the United States and Africa: The challenges of productive engagement. Comparative Studies of South Asia, Africa and the Middle East 24(I), 26I-275.

Zeleza, P. (20I3). Engagements between African diaspora academics in the US and Canada and African institutions of higher education: Perspectives from North America and Africa. New York: Carnegie Corporation. 